\title{
Screening for Genes Coding for Putative Antitumor Compounds, Antimicrobial and Enzymatic Activities from Haloalkalitolerant and Haloalkaliphilic Bacteria Strains of Algerian Sahara Soils
}

\author{
Okba Selama, ${ }^{1}$ Gregory C. A. Amos, ${ }^{2}$ Zahia Djenane, ${ }^{1}$ Chiara Borsetto, ${ }^{2}$ Rabah Forar Laidi, ${ }^{3}$ \\ David Porter, ${ }^{2}$ Farida Nateche, ${ }^{1}$ Elizabeth M. H. Wellington, ${ }^{2}$ and Hocine Hacène ${ }^{1}$ \\ ${ }^{1}$ Microbiology Group, Laboratory of Cellular and Molecular Biology, Faculty of Biological Sciences, USTHB, BP 32, EL ALIA, \\ Bab Ezzouar, Algiers, Algeria \\ ${ }^{2}$ School of Life Sciences, University of Warwick, Coventry CV4 7AL, UK \\ ${ }^{3}$ Department de Biologie, Ecole Normale Superieure (ENS), Vieux Kouba, Alger, Algeria \\ Correspondence should be addressed to Hocine Hacène; h_hacene@yahoo.fr
}

Received 26 February 2014; Revised 13 April 2014; Accepted 6 May 2014; Published 27 May 2014

Academic Editor: Ameur Cherif

Copyright (C) 2014 Okba Selama et al. This is an open access article distributed under the Creative Commons Attribution License, which permits unrestricted use, distribution, and reproduction in any medium, provided the original work is properly cited.

\begin{abstract}
Extreme environments may often contain unusual bacterial groups whose physiology is distinct from those of normal environments. To satisfy the need for new bioactive pharmaceuticals compounds and enzymes, we report here the isolation of novel bacteria from an extreme environment. Thirteen selected haloalkalitolerant and haloalkaliphilic bacteria were isolated from Algerian Sahara Desert soils. These isolates were screened for the presence of genes coding for putative antitumor compounds using PCR based methods. Enzymatic, antibacterial, and antifungal activities were determined by using cultural dependant methods. Several of these isolates are typical of desert and alkaline saline soils, but, in addition, we report for the first time the presence of a potential new member of the genus Nocardia with particular activity against the yeast Saccharomyces cerevisiae. In addition to their haloalkali character, the presence of genes coding for putative antitumor compounds, combined with the antimicrobial activity against a broad range of indicator strains and their enzymatic potential, makes them suitable for biotechnology applications.
\end{abstract}

\section{Introduction}

There is an increasingly urgent need for new active biomolecules and enzymes for use in industry and therapy [1]. However, the rate of discovery of new useful compounds has been in decline $[2,3]$ and because of this there is an interest in investigating previously unexplored ecological niches $[4,5]$, particularly extreme environments. These environments have provided a useful source of novel biologically active compounds in recent years $[1,6,7]$.

Extreme environments are distributed worldwide. These ecosystems were thought to be lifeless as insurmountable extreme physical and chemical barriers to life exhibit. With the advancement of our knowledge, we now see them as yet another niche harbouring "extremophiles" [8]; major categories of extremophiles include halophiles, thermophiles, acidophiles, alkaliphiles, and haloalkaliphiles $[6,9]$.

The haloalkaliphiles bacteria have attracted a great deal of attention from researchers in this last decade [9]. In 1982, the term haloalkaliphile was used for the first time to describe bacteria that are both halophilic and alkaliphilic [10]. This group of bacteria is able to grow optimally or very well at $\mathrm{pH}$ values at or above 10 along with high salinity (up to $25 \%$ (w/v) $\mathrm{NaCl})[11]$.

To encounter such harsh conditions, haloalkaliphilic microorganisms have found various physiological strategies to sustain their cell structure and function $[12,13]$. These bacteria have widely been identified and studied from the 
hypersaline environments, soda lakes, solar saltern, salt brines, carbonate springs, and Dead Sea [14]. Their survival obviously indicated the widespread distribution of such organisms in natural saline environments $[12,15]$.

The interest in haloalkaliphilic microorganisms is due not only to the necessity for understanding the mechanisms of adaptation to multiple stresses and detecting their diversity, but also to their possible application in biotechnology [9].

The present work involved the isolation and characterization of new haloalkalitolerant and haloalkaliphilic bacteria able to produce extremozymes and elaborate natural bioactive compounds effective against pathogenic bacteria and fungi as well. The screening for genes coding for putative antitumor compounds by PCR with three sets of primers was also performed. We have been interested in soils of Algerian Sahara Desert, which is one of the biggest deserts and encompasses one of the most extreme environments worldwide (Sabkha and Chott). However, it is also considered to be one of the less explored parts. Our team has been interested in these magnificent ecosystems for many years and the few studies that have been published have shown great active biomolecules [16-18], biodiversity of interesting new taxa [19-24], and enzymes [25, 26].

\section{Material and Methods}

2.1. Sampling and Strains Isolation. Samples from different soils (7 sites) of Algeria's Sahara Desert were collected on March 2010 (100-300 g per site in sterile bags) (Figure 1). Most samples were saline and alkaline soils, with an electrical conductivity between 1.4 and $20.2 \mathrm{mS} / \mathrm{cm}$ (at $20^{\circ} \mathrm{C}$ ) and $\mathrm{pH}$ range of 7.5-9; the temperature varies from $22^{\circ} \mathrm{C}$ north to $44^{\circ} \mathrm{C}$ south of the Sahara. One gram from each sample was suspended in $9 \mathrm{ml}$ sterile water (of $0.9 \%, 10 \%$, and $20 \% \mathrm{NaCl}$ $\mathrm{w} / \mathrm{v}$ ) and serial dilutions to $10^{-4}$. For each dilution and for each concentration, soil particles were allowed to sediment; then $0.1 \mathrm{~mL}$ of the liquid phase was spread onto the surface of each of the modified International Streptomyces Project 2 (ISP2) [27] media agar supplemented with $\mathrm{NaCl}$ with respect to the various concentrations of salt used for dilutions $(0.9 \%$, $10 \%$, and $20 \% \mathrm{NaCl} \mathrm{w/v)} \mathrm{and} \mathrm{adjusted} \mathrm{to} \mathrm{either} \mathrm{pH}=7$ or $\mathrm{pH}=10$ by adding $5 \mathrm{M} \mathrm{NaOH}$ before autoclaving and spread onto nutrient agar plates. The plates were maintained at constant humidity incubated at either $30^{\circ} \mathrm{C}$ or $50^{\circ} \mathrm{C}$ for 15 days. Colonies were picked out and repeatedly restreaked until purity was confirmed. All bacterial culture isolates were stored at $4^{\circ} \mathrm{C}$ in the same medium used for isolation.

2.2. Physiological Growth Parameters. Physiological growth parameters for the thirteen selected strains were determined by agar plate method on modified ISP2 medium depending on the modified parameter. Salinity tolerance was examined for $0,1,5,10,15,20$, and $25 \% \mathrm{NaCl} w / v$. The $\mathrm{pH}$ growth range was investigated between $\mathrm{pH} 5$ and 12 at intervals of $1 \mathrm{pH}$ unit. The temperatures tested were $4,10,15,20,25,30,37$, $40,42,45,55$, and $60^{\circ} \mathrm{C}$. Incubation time was one week for Actinobacteria and two days for non-Actinobacteria.

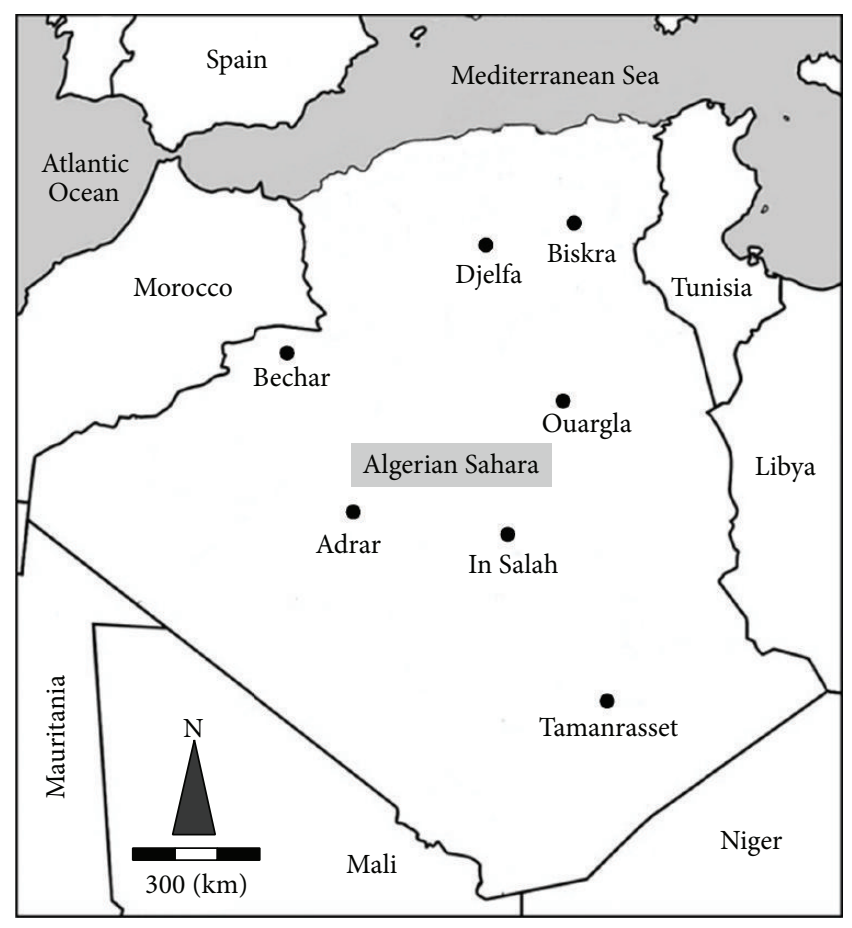

FIGURE 1: Location of the sampled sites from Algerian Sahara Desert. Djelfa: $35^{\circ} 16^{\prime} 47.5^{\prime \prime} \mathrm{N} 3^{\circ} 43^{\prime} 25.4^{\prime \prime} \mathrm{E}$; Biskra: $34^{\circ} 11^{\prime} 01.1^{\prime \prime} \mathrm{N} 6^{\circ} 07^{\prime} 21.8^{\prime \prime} \mathrm{E}$; Ouargla: $33^{\circ} 29^{\prime} 28.85$ N $5^{\circ} 59^{\prime} 10.52^{\prime \prime}$ E; Tamanrasset $23^{\circ} 00^{\prime} 30.01^{\prime \prime} \mathrm{N}$ $5^{\circ} 13^{\prime} 33.32^{\prime \prime}$ E; In Salah: $27^{\circ} 11^{\prime} 31.60^{\prime \prime} \mathrm{N} 2^{\circ} 27^{\prime} 12.52^{\prime \prime}$ E; Adrar: $27^{\circ} 44^{\prime} 48.14^{\prime \prime} \mathrm{N} 0^{\circ} 16^{\prime} 10.21^{\prime \prime} \mathrm{W}$; Bechar: $30^{\circ} 51^{\prime} 25.71^{\prime \prime} \mathrm{N} 1^{\circ} 59^{\prime} 58.56^{\prime \prime}$ $\mathrm{W}$.

\subsection{Molecular Study}

2.3.1. DNA Extraction. Total genomic DNA from the different selected bacteria for this study was isolated and purified using Qiagen Blood and Tissue DNA extraction kit (Qiagen, UK). DNA was eluted in Tris-HCL and its quantity and quality were tested using NanoDrop 2000 (Thermo Scientific). DNA was stored at $-20^{\circ} \mathrm{C}$ until use.

2.3.2. Molecular Identification. The amplification of $16 \mathrm{~S}$ rRNA gene for the selected strains was performed using the universal bacterial primer pairs $\mathrm{pA} / \mathrm{pH}$ designed by Edwards et al. [28] (Table 1). PCR reactions were performed in final reaction volume of $50 \mu \mathrm{L}$ containing $1 \mu \mathrm{L}$ (10-100 ng) of DNA template, $25 \mu \mathrm{L}$ master mix (Promega, Madison, WI, USA), $1 \mu \mathrm{L}(10 \mu \mathrm{M})$ of each primer, and $1 \mu \mathrm{L}$ of BSA (10 mg/mL) (Promega, Madison, WI, USA). PCR products were analyzed on $1.5 \%(\mathrm{w} / \mathrm{v})$ agarose (Sigma, UK) in $40 \mathrm{mM}$ Tris-acetate with $1 \mathrm{mM}$ EDTA (TAE) buffer at $\mathrm{pH}$ of 8.0 stained with ethidium bromide at $0.5 \mu \mathrm{g} \mathrm{mL}^{-1}$. Bands of the corresponding size were cut out and purified with gel extraction kit (Qiagen; Venlo, Netherlands) as per the manufacturer's instructions.

The nucleotide sequences for the 16S rRNA gene of the different strains were carried out by GATC Biotech (UK). The isolates were identified using the EzTaxon-e server (http://eztaxon-e.ezbiocloud.net/) on the basis of 16S rRNA sequence data [32]. 
TABle 1: Primers used in this study.

\begin{tabular}{|c|c|c|c|c|}
\hline Primers & Gene & Molecules & Reference & PCR programs \\
\hline $\begin{array}{l}\text { pA: AGAGTTTGATCCTGGCTCAG } \\
\text { pH: AAGGAGGTGATCCAGCCGCA } \\
1,5 \mathrm{~Kb}\end{array}$ & 16S RNA & $/ / / / / / / / / / /$ & {$[28]$} & $\begin{array}{l}\text { PCR cycles were as follows: } 1 \text { cycle at } \\
95^{\circ} \mathrm{C} \text { for } 10 \mathrm{~min} ; 35 \text { cycles at } 94^{\circ} \mathrm{C} \text { for } \\
1 \mathrm{~min}, 55^{\circ} \mathrm{C} \text { for } 1 \mathrm{~min} \text {, and } 72^{\circ} \mathrm{C} \text { for } \\
2 \mathrm{~min} \text {; one final cycle at } 72^{\circ} \mathrm{C} \text { for } \\
10 \mathrm{~min} \text {. }\end{array}$ \\
\hline $\begin{array}{l}\text { Glu1: CSGGSGSSGCSGGSTTCATSGG } \\
\text { Glu2: GGGWRCTGGYRSGGSCCGTAGTTG } \\
546 \text { bp }\end{array}$ & $\begin{array}{l}\text { dNDP-Glucose-4,6- } \\
\text { dehydratases }\end{array}$ & $/ / / / / /$ & [29] & $\begin{array}{l}\text { PCR conditions used were } 95^{\circ} \mathrm{C} \text { for } \\
4 \mathrm{~min} ; 30 \text { cycles of } 95^{\circ} \mathrm{C} \text { for } 30 \mathrm{~s}, 65^{\circ} \mathrm{C} \\
\text { for } 30 \mathrm{~s} \text {, and } 68^{\circ} \mathrm{C} \text { for } 1.30 \mathrm{~min} \text {; and a } \\
\text { final extension cycle at } 68^{\circ} \mathrm{C} \text { for } 5 \mathrm{~min} .\end{array}$ \\
\hline $\begin{array}{l}\text { StaDVF: GTSATGMTSCAGTACCTSTACGC } \\
\text { StaDVR: YTCVAGCTGRTAGYCSGGRTG. } \\
570 \text { bp }\end{array}$ & $\begin{array}{l}\text { Oxytryptophan } \\
\text { dimerization genes } \\
\text { (StaD/RebD/VioB) } \\
\text { (indolotryptoline } \\
\text { biosynthetic gene } \\
\text { cluster) }\end{array}$ & $\begin{array}{l}\text { BE-54017, } \\
\text { (tryptophan } \\
\text { dimmers) }\end{array}$ & {$[30]$} & $\begin{array}{l}\text { PCR protocol: } 1 \text { cycle of } 95^{\circ} \mathrm{C} \text { for } \\
5 \mathrm{~min} ; 7 \text { cycles of } 95^{\circ} \mathrm{C} \text { for } 30 \mathrm{sec}, 65^{\circ} \mathrm{C} \\
\text { for } 30 \mathrm{sec} \text { with } 1^{\circ} \mathrm{C} \text { decrement per cycle } \\
\text { to } 59^{\circ} \mathrm{C} \text {, and } 72^{\circ} \mathrm{C} \text { for } 40 \mathrm{sec} ; 30 \mathrm{cycles} \\
\text { of } 95^{\circ} \mathrm{C} \text { for } 30 \mathrm{sec}, 58^{\circ} \mathrm{C} \text { for } 30 \mathrm{sec} \text {, and } \\
72^{\circ} \mathrm{C} \text { for } 40 \mathrm{sec} ; 1 \mathrm{cycle} \text { of } 72^{\circ} \mathrm{C} \text { for } \\
7 \mathrm{~min} \text {; hold at } 4^{\circ} \mathrm{C}\end{array}$ \\
\hline $\begin{array}{l}\text { AuF3: GAACTGGCCSCGSRTBTT } \\
\text { AuR4: CCNGTGTGSARSKTCATSA } \\
\text { 600-700 bp }\end{array}$ & $\begin{array}{l}\text { Iadomycin } \\
\text { cyclase gene of } \\
\text { Streptomyces } \\
\text { venezuelae ISP5230 }\end{array}$ & $\begin{array}{l}\text { Angucycline } \\
\text { cyclases } \\
\text { Marine } \\
\text { sponge }\end{array}$ & {$[31]$} & $\begin{array}{l}\text { Optimized PCR conditions were as } \\
\text { follows: (1) denaturation at } 94^{\circ} \mathrm{C} \text { for } \\
5 \mathrm{~min},(2) 30 \text { amplification cycles with } \\
\text { denaturation }\left(45 \mathrm{~s}, 94^{\circ} \mathrm{C}\right) \text {, annealing } \\
\left(60 \mathrm{~s}, 60^{\circ} \mathrm{C}\right) \text {, and extension }(60 \mathrm{~s} \text {, } \\
\left.72^{\circ} \mathrm{C}\right) \text {, and }(3) \text { a final extension at } 72^{\circ} \mathrm{C} \\
\text { for } 8 \mathrm{~min} \text {. }\end{array}$ \\
\hline
\end{tabular}

The Molecular Evolutionary Genetics Analysis (MEGA) software, version 4.0.2, was used to assist the phylogenetic analyses and the phylogenetic tree construction [33]. Similar $16 \mathrm{~S}$ rRNA gene sequences for the studies of the strains were obtained by using Eztaxon [32]. Multiple alignments of data were performed by CLUSTAL W [34]. Evolutionary distances were calculated by using maximum composite likelihood method and are in the units of the number of base substitutions per site [35]. Phylogenetic tree was reconstructed with the neighbour-joining algorithm [36]. Topology of the resultant tree was evaluated by bootstrap analyses of the neighbour-joining dataset, based on 1000 resamplings [37].

The sequences reported in this study have been submitted to NCBI GenBank and the accession numbers are listed in appendices.

\subsection{Screening}

2.4.1. Primers and Molecular Screening. From the thirteen selected strains, six were subjected to molecular screening for genes coding for putative antitumor compounds using three primer sets (Table 1). These strains were chosen on the basis of the presence of nonribosomal peptide synthetases/ polyketide synthases (NRPS/PKS) genes within their genomes (data not published). The first set designed by Decker et al. [29] amplified dNDP-glucose dehydratase genes. The second set was that of Chang and Brady [30] used to screen for biosynthesis of the antitumor substance BE-54017. The final set was used from the study of Ouyang et al. [31] targeting the jadomycin cyclase gene which intervenes in angucycline production.
The PCR mixture included $1-2 \mu \mathrm{L}$ of genomic DNA, $15 \mu \mathrm{L}$ master mix (Sigma,UK), $1 \mu \mathrm{L}$ each of forward and reverse primers (10 $\mu \mathrm{M}$ each) (Sigma, UK), $1 \mu \mathrm{L}$ of BSA $(10 \mathrm{mg} / \mathrm{mL})$ (Promega, Madison, WI, USA), and $6 \mu \mathrm{L}$ sterile distilled water in a final volume of $25 \mu \mathrm{L}$. PCR was performed with Mastercycler pro (Eppendorf). Agarose gels (1\% w/v) were photographed after staining with ethidium bromide at $0.5 \mu \mathrm{g} \mathrm{mL}{ }^{-1}$ with a minivisionary imaging system. Sizes of the fragments were estimated using the Fermentas $1 \mathrm{~kb}$ Plus DNA ladder (Fermentas, UK).

2.4.2. Antimicrobial Activities Test. Antimicrobial activity was determined by the agar cylinder diffusion method. A $6 \mathrm{~mm}$ diameter cylinder was taken from solid cultures and put on preseeded nutrient agar plate of the targeted microorganisms mentioned below. Up to five cylinders of different bacteria per plate were tested. Inhibition zones were expressed as diameter and measured after incubation at $37^{\circ} \mathrm{C}$ for $24 \mathrm{~h}$ for bacteria and at $28^{\circ} \mathrm{C}$ for $48-72 \mathrm{~h}$ for the filamentous fungus and yeasts [38].

Reference strains used in this study were as follows.

Sa: Staphylococcus aureus ATCC 25923, Ml: Micrococcus luteus ATCC 9341, Ec: Escherichia coli ATCC 25922, Pa: Pseudomonas aeruginosa ATCC 27853, Ca: Candida albicans (clinical isolate, Algerian Central Hospital of Army of Algeria), Foa: Fusarium oxysporum $f$. sp. albedinis a filamentous phytopathogenic fungi for date palm (Algerian National Institute for Plant Protection), and Sc: Saccharomyces cerevisiae.

2.4.3. Enzymatic Screening. Enzymatic activities "amylolytic, proteolytic (caseinase), and lipolytic" were screened using 
zone clearance assays. The enzymatic substrate was incorporated to the media, and the strains were restreaked by spots [39]. The tests were conducted with respect to physiological growth parameters of each strain.

\section{Results}

3.1. Strains Isolation and Selection. Isolation plates developed various types of colonies. Sixty to hundred colonies were found per plate in the first dilution for almost all soils, two to ten colonies were observed in the third dilution, and almost nothing in the fourth dilution plates. We have also seen that for the same dilution the number of colonies decreases when the concentration of $\mathrm{NaCl}$ increases. One to five colonies which looked less represented were selected from each plate with respect to the haloalkaliphilic character. A total of thirtynine isolates were distinguished. Amongst these thirty-nine isolates (17 were filamentous, 17 bacilli form, and 5 were cocci form), thirteen strains-eleven with particular morphology (filamentous, which may indicate Actinobacteria that are best known for the production of active biomolecules), one bacilli form, and one cocci form-were the subject of our study. The macroscopic and microscopic aspects of three of the thirteen strains are represented in Figure 2. The molecular identification by EzTaxon-e, physiological growth parameters, and enzymatic screening are described in Table 2. The alphabetical strains code used in our study refers to the geographical area origin of isolation; the numerical strains code part is a simple sequential order to differentiate strains.

3.2. Physiological Growth Study. All strains could tolerate up to $5 \% \mathrm{NaCl}$. Strains Reg1, Ker5, and HHS1 were able to tolerate up to $10 \%$, whereas Bisk4 could tolerate up to $15 \%$. Tag5 growth started at $1 \%$ and M5A started growing at $10 \%$; these two strains could grow up to $20 \% \mathrm{NaCl}$. Reg1, Ker5, and HHS1 are considered as halotolerant. M5A and Tag5 are considered to be halophilic [40].

All strains except A60 had a versatile range of growth $\mathrm{pH}$ (5-12) indicating alkaliphilic growth; A60 (5-9) was only alkalitolerant.

Beside the alkalitolerant character of strain A60, it presented a thermophilic profile $\left(45-60^{\circ} \mathrm{C}\right)$. With the exception of strain Bisk4, which may be considered as thermotolerant bacteria since it grows up to $55^{\circ} \mathrm{C}$, the other selected bacteria are considered to be mesophiles.

3.3. Identification. Most isolated strains belonged to the genus Streptomyces (AT1, ASB, GB1, Ig6, and GB3). The five Actinobacteria, other than Streptomyces, were identified as follows: Reg1 and Ker5 as two different Nocardiopsis sp., HHS1 as Pseudonocardia sp., M5A as Actinopolyspora sp., and Bisk2 as Nocardia sp. Bisk2 looks like a new member as it branches out $100 \%$ of the time from its nearest relative Nocardia jejuensis determined by EzTaxon-e with 95\% similarity for the 750 recovered bases. One filamentous strain A60 was identified as Thermoactinomyces sp. The bacilli Bisk4 is part of the Bacillus mojavensis complex and the cocci Tag5 belonged to the genus Marinococcus (Table 2; Figure 3).

\subsection{Screening for Biotechnological Potential}

3.4.1. Screening for Genes Coding for Putative Antitumor Compounds. Glu1/Glu2 primer set had 4/6 positives. High intensity band was registered for the strain Ig6. The primers targeted two different regions for the strain Bisk2. Multiple bands were recovered from the strain GB1 while no one range $500-700 \mathrm{pb}$. PCR using this primer was negative for the strain A60 (Figure 4(a)). The StaDVF/StaDVR primer set was positive in one strain (Figure 4(b)). The PCR with $\mathrm{AuF} 3 / \mathrm{AuF} 4$ primer set was negative for all tested strains (Figure 4(c)).

3.4.2. Antimicrobial Activity. The antimicrobial activity of the thirteen selected strains differed between strains (Table 2; Figure 5). Among these, eight showed at least an antimicrobial activity against one of the targeted microorganisms. A highly broad spectrum antimicrobial activity inhibition was seen by the strain Streptomyces sp. (GB3). The strain Bacillus sp. (Bisk4) had gram positive antibacterial activity and antifungal activity against the filamentous fungi. The strain Actinopolyspora sp. (M5A) inhibited the growth of Micrococcus luteus. The isolate Nocardia sp. (Bisk2) showed a unique and selective activity against the yeast Saccharomyces cerevisiae (Figure 5(c)). However, none of the thirteen strains demonstrate specific and unique activity against the gram negative bacteria.

3.4.3. Enzymatic Activity. Strains from Bacillus and Streptomyces were more enzymatically active and possess at least two of the screened enzymes. The strain Thermoactinomyces sp. (A60) was able to degrade casein and lipids. Strains Bisk2, TAG5, and HHS1 seemed to have none of these screened enzymes (Figure 6).

\section{Discussion}

In this study we looked at extreme environment of the Algerian Sahara Desert as a source for novel strains possessing interesting bioactive properties. In total, we isolated a collection of thirty-nine haloalkalitolerant and haloalkaliphilic isolates, thirteen of which were selected and screened for genes coding for putative antitumor compounds, as well as screening for antimicrobial and enzymatic activities. All strains were identified using 16S rRNA gene sequencing. This study represents novelty in looking at the relatively understudied areas of Sabkha and Chott and has yielded at least thirteen strains which potentially have antitumorgenic, antimicrobial, and enzymatic properties.

Although often extreme and hostile ecosystems diversity and abundance of bacteria can be low ranging from 10 to $10^{4} \mathrm{UFC} / \mathrm{g}$ of soil where the physicochemical parameters are controlling factors [19], the strains retrieved and identified in our study, in particular, of Actinobacteria strains, which belong to various taxa, indicate a great diversity. Diversity in environments such as the one in this study has previously been investigated such as in Tunisia [9], China [41], and 


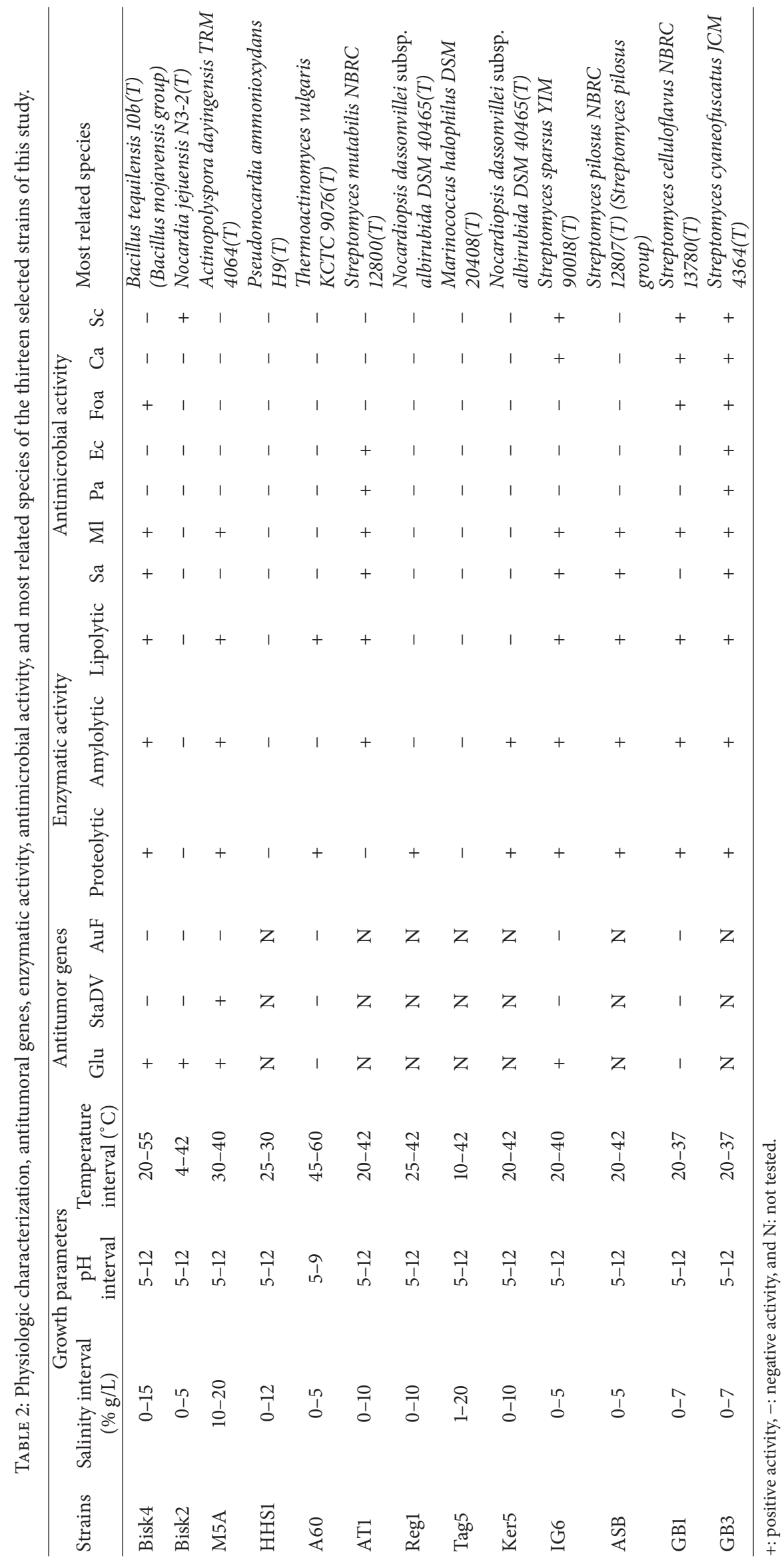



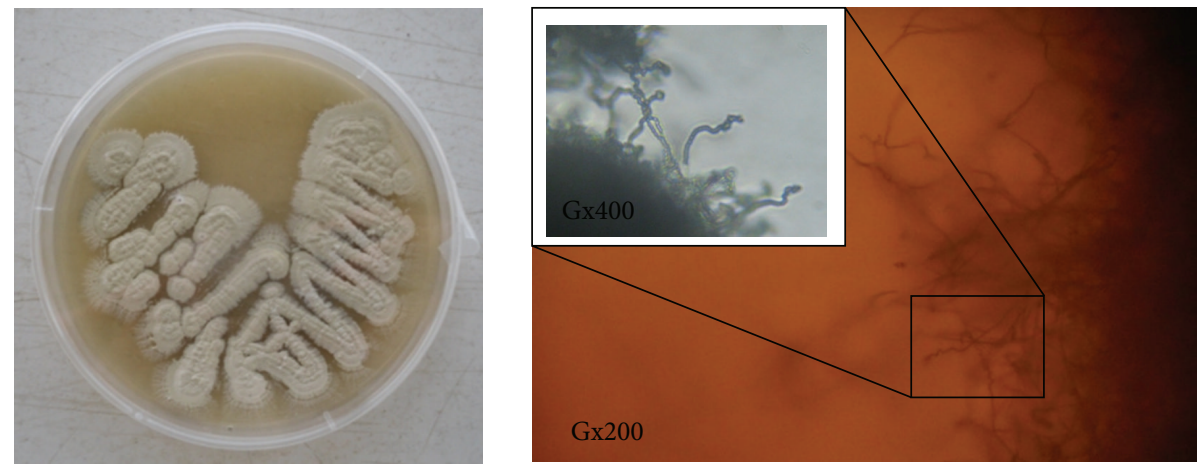

(a)
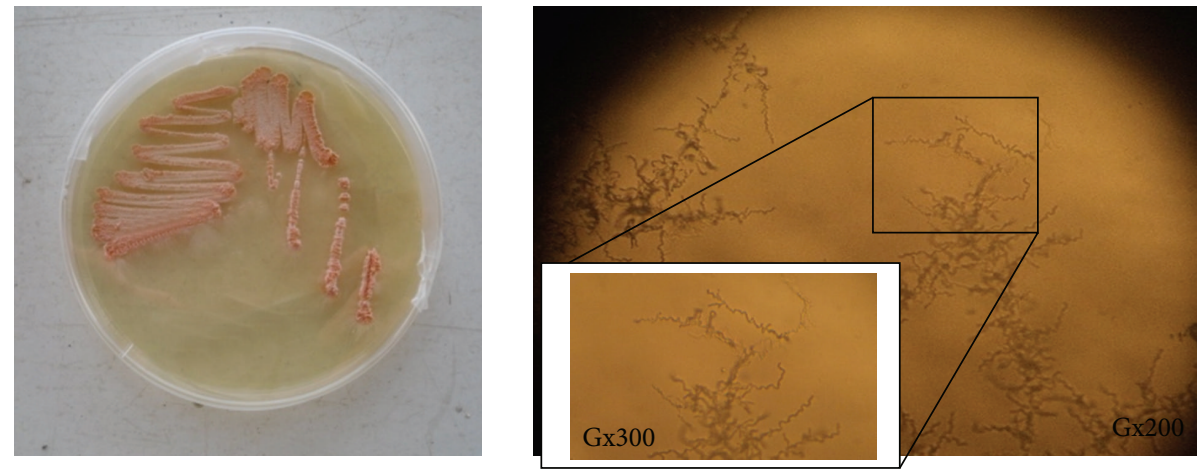

(b)
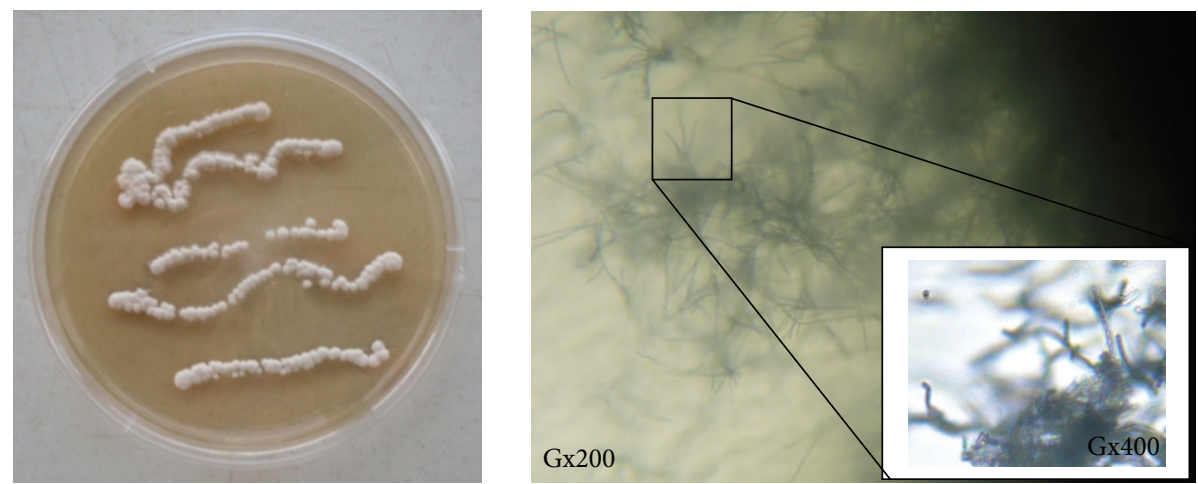

(c)

FIgURE 2: Macroscopic morphology (left) on ISP2 and microscopic filamentous morphology (right) of three strains of this study. (a) Strain IG6: spiral chain of spores on aerial mycelium. (b) Strain Bisk2: nocardioform mycelium. (c) Strain M5A: long straight chains of spores on aerial mycelium.

previously in the Algerian Sahara soils [19, 42], which has revealed that members of these extreme ecosystems are mainly halotolerant or halophilic organisms. Many of the isolated taxa in this study have previously been found in this environment, particularly of the Actinopolyspora, Nocardiopsis, and Marinococcus [9, 41-43]. Despite this their community structure differs both quantitatively and qualitatively for each different ecosystem. This would be due not only to the adaptation to environmental obstacles but also to the geolocalisation [43], the difference of the study protocol (method, media) [41], and the sampling sites [42].
Genome sequencing followed by bioinformatics analysis for some of the already sequenced microorganisms such as Actinobacteria and Bacillus has revealed the presence of several gene clusters per genome that can produce different molecules [44]. Among the validly described halotolerant and halophilic bacteria, particularly Actinobacteria, only few numbers have been subjected to analysis of their bioactive compounds [45]. In addition, many compounds are usually produced in very low amounts (or not at all) under typical laboratory conditions [46]. PCR based methods for specific enzymes activating specific molecules are excellent screening tools for these strains; they would not only indicate the 


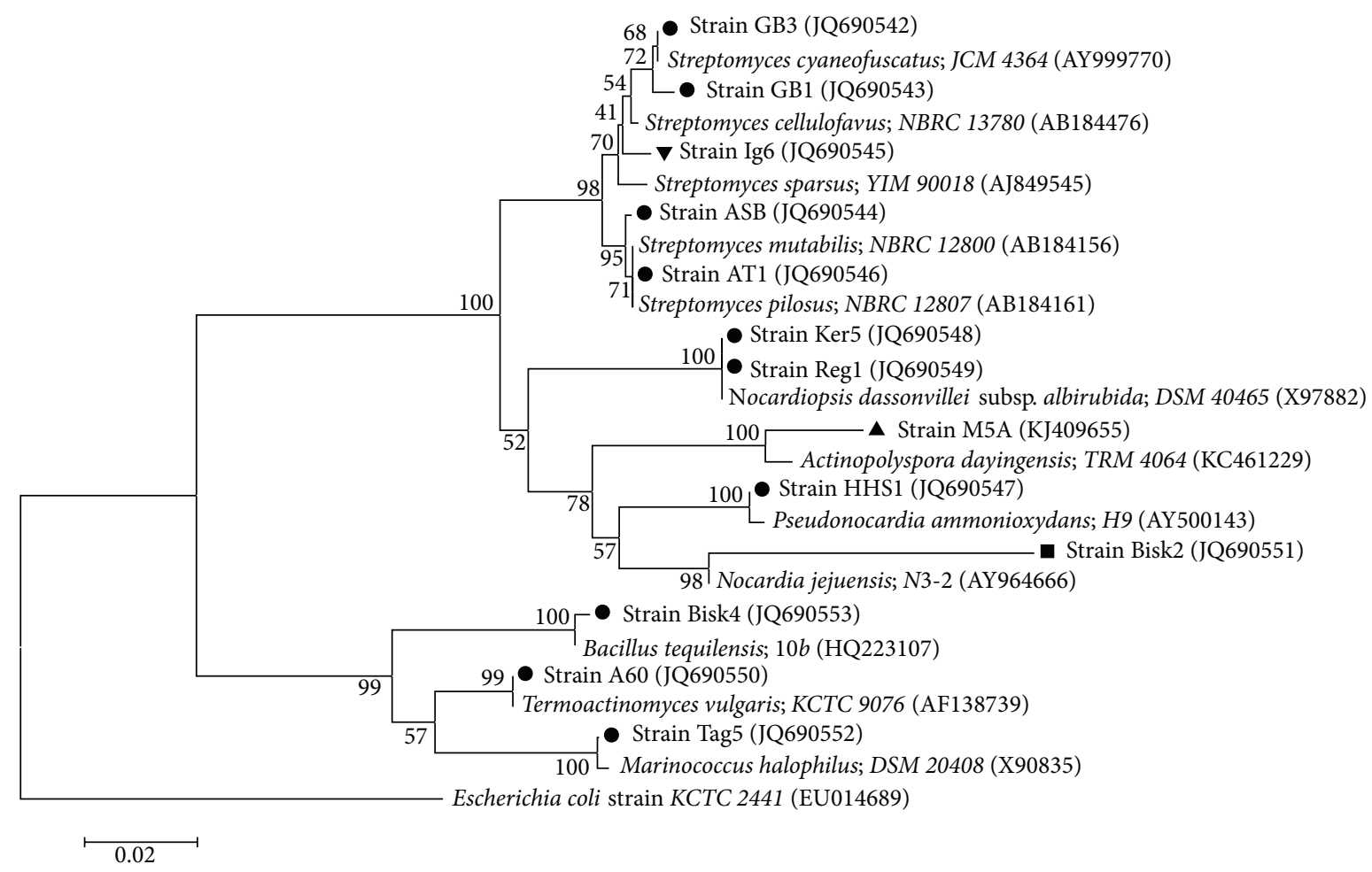

FIGURE 3: Molecular phylogeny of thirteen selected bacteria and the most related type strains species using partial 16S rRNA sequences. The evolutionary distances were computed using the maximum composite likelihood method and are in the units of the number of base substitutions per site. Tree topology was constructed using MEGA 4.0. Bootstrap values $(n=1000$ replicates) were indicated at the nodes. Escherichia coli KCTC2441 sequence was added as an out group for this tree.

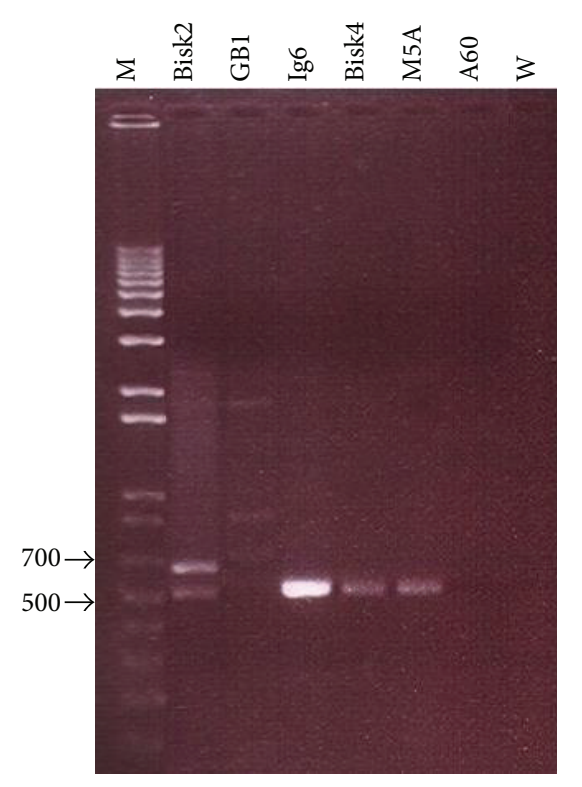

(a)

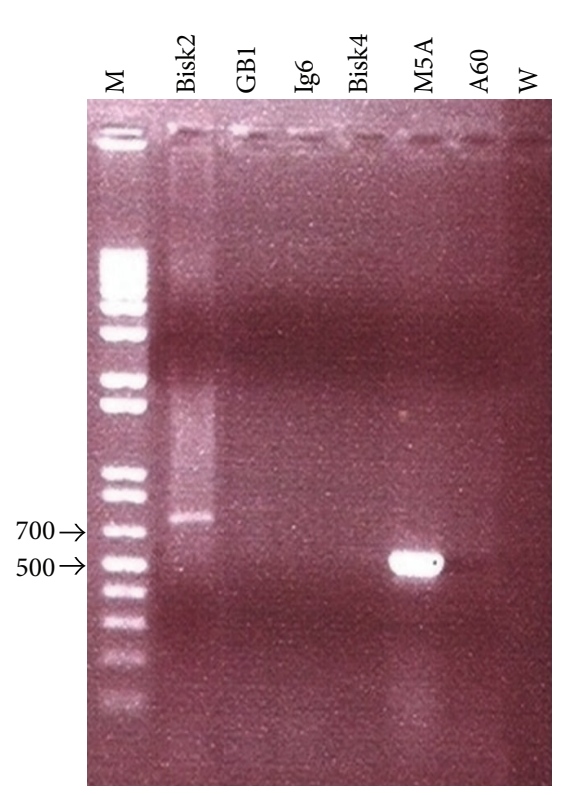

(b)

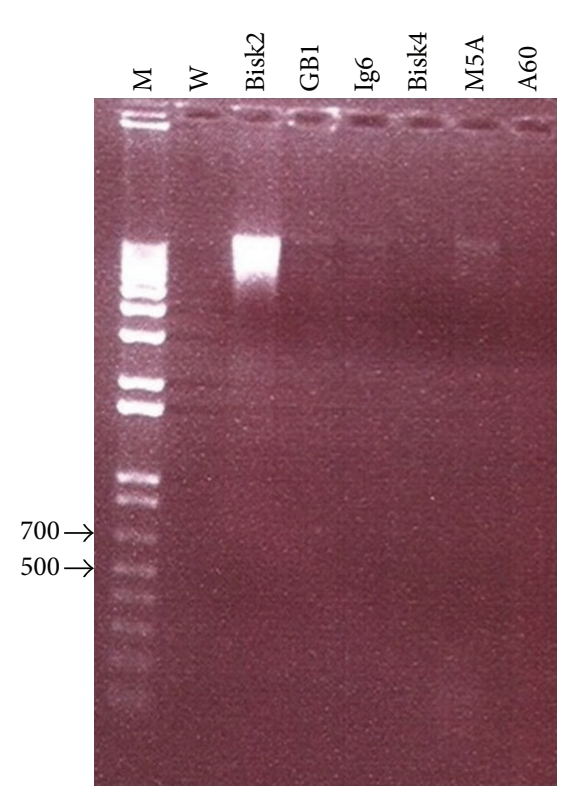

(c)

FIGURE 4: Agarose gel electrophoresis of PCR products from genomic DNA of six strains of the present study with selective fragments amplification range 500-700 bp using primers: (a) Glu1/Glu2, (b) StaDVF/StaDVR, and (c) AuF3/AuF4. M: 1 kb Plus DNA ladder; W: water control. 


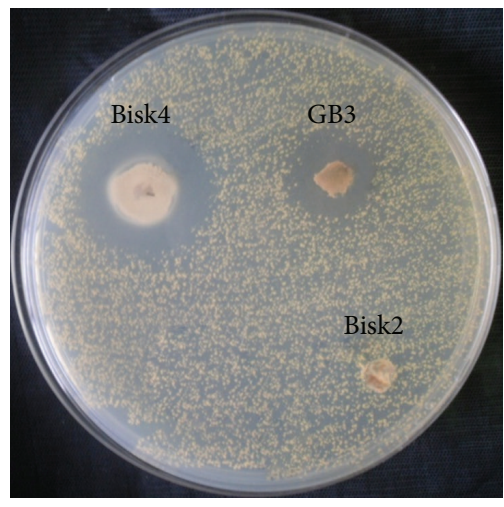

(a)

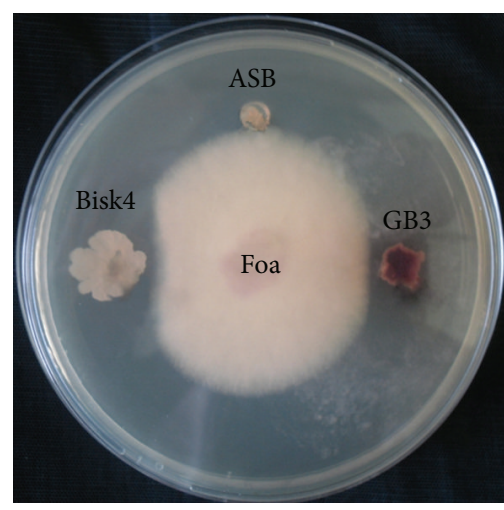

(b)

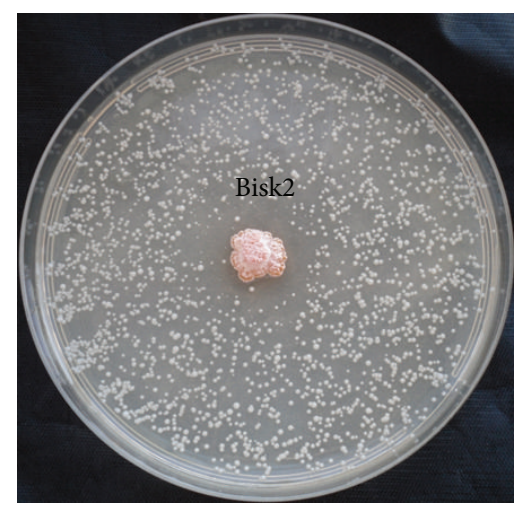

(c)

FIGURE 5: Antimicrobial activity of some strains among the selected strains: (a) antibacterial activity against Staphylococcus aureus, (b) antifungal activity against Fusarium oxysporum $f$. sp. albedinis, and (c) antifungal activity of the strain Nocardia sp. (Bisk2) against the yeast Saccharomyces cerevisiae.

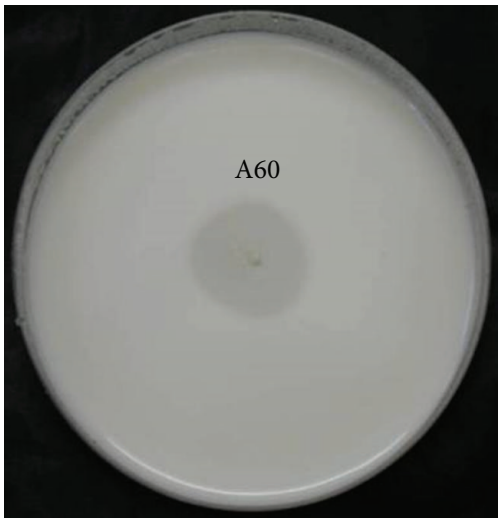

(a)

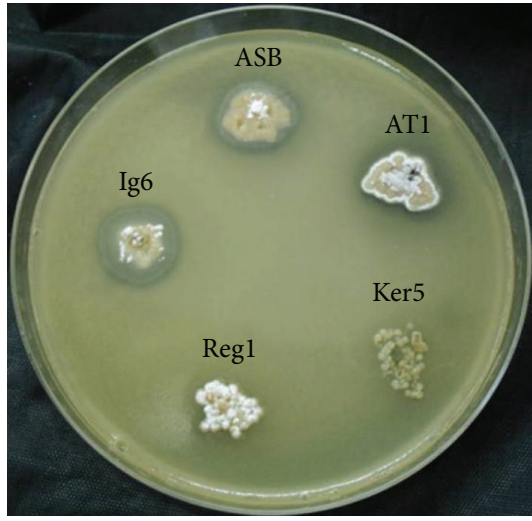

(b)

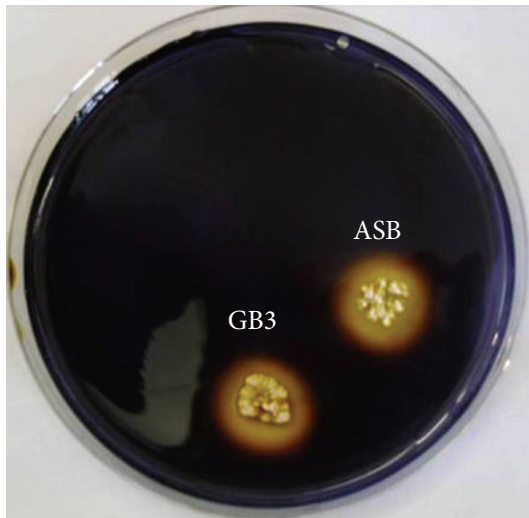

(c)

FIGURE 6: Enzymatic activities of some strains among the selected strains. (a) Proteases (caseinase), (b) lipases, and (c) amylases.

presence of probable genes clusters but also help in biochemical characterisation of the molecules. These methods would help in reducing the number of strains that need to be screened by cultural methods. The PCR based methods not only are limited to genomic DNA but also can be applied for the screening of eDNA that lead to the discovery of new active biomolecules [30]. Screening for potential production of a particular type of biomolecules such as antibiotics and antitumorales, without going through the tedious biochemistry process, is more efficient when the typing protocol is targeting the biosynthesis gene cluster rather than the taxonomic marker genes (e.g., 16S rRNA gene) which often give misleading results $[47,48]$.

In our study, we have been interested in molecular screening of bioactive genes coding for putative antitumor compounds. The degenerate primers Glu1/Glu2 for the conserved N-terminal sequence of dNDP-glucose 4,6dehydratase genes have been extensively used to screen out for clusters of active biomolecules with antitumoral activity such as novobiocin [49], enediyne [50], elloramycin [51], sibiromycin [52], ravidomycin, and chrysomycin [53].
The primer set has also been reported in other screening studies for talosins A and B cluster, an antifungal [54], for caprazamycin biosynthesis, an antimycobacterial [55], and more recently we have used this set to screen for amicetin biosynthesis gene cluster, an antibacterial and antiviral agent [56]. The second primer set was designed by Chang and Brady [30] who screened a previously archived soil eDNA cosmid library by PCR using degenerate primers designed to recognize conserved regions in known oxytryptophan dimerization genes (StaD/RebD/VioB etc). The oxytryptophan dimerization enzymes were chosen as probes because this enzyme family is used in the biosynthesis of structurally diverse tryptophan dimmers, which have shown an antitumoral activity. Both indolocarbazole biosynthetic gene clusters (e.g., staurosporine, rebeccamycin, K-252a, and AT2433) and violacein biosynthetic gene clusters contain homologous enzymes that carry out the oxidation (StaO/RebO/VioA) and subsequent dimerization (StaD/RebD/VioB) of tryptophan. One among the six screened strains was positive for the set of the primers, strain M5A. This would signify that the strain M5A could produce tryptophan dimmers compound(s). 
The sequencing result followed by blast for the PCR products of M5A using StaDVF/StaDVR primers set (GenBank: KJ560370) has shown 76\% homology to the uncultured bacterium clone AR1455 rebeccamycin-like tryptophan dimer gene cluster (GenBank: KF551872) that was studied by Chang and Brady [30], while, for the strains Streptomyces sp. Ig6, it has shown a mixed PCR product; we think this is probably due to the presence of multiple variable copies of this gene in this strain.

The different patterns of activity against the targeted microorganisms observed in this study may indicate a variety of the produced active biomolecules. The antimicrobial activity of Bisk2, most closely related to Nocardia jejuensis [57], has never been reported to our knowledge. This result encourages us to consider Bisk2 as probably a new member or at least a new strain of Nocardia. Genome sequencing, DNADNA hybridising, and molecular chemotaxonomy would give more knowledge about its taxonomic position among the Nocardia species.

The Sahara Desert is subject to large fluctuations in parameters such as temperature, $\mathrm{pH}$, or salinity. It is populated by communities of organisms with intrinsic genomic heterogeneity for adaptation. The mechanisms of cell adaptation engage several enzymatic processes that may be a source of enzymes that show a higher level of stability and activity over a wider range of conditions. The screened enzymes found in this study (proteases, amylases, and lipases) would be economically valuable since they were screened from such environments and are likely to exhibit rare properties; these extremozymes are of great value to biotechnology industries $[7,58,59]$.

\section{Conclusion}

Exploration of biodiversity and biotechnological potential of desert microorganisms has gone several steps forward in recent years. The Sahara Desert is one of the biggest worldwide. It spreads upon several countries of Africa. These countries are among the countries worldwide to have the smallest registration rates of biodiversity in biological databases [60].

In addition to the insights on the biodiversity of Algerian Sahara Desert, to our knowledge, this is the first time to use the molecular screening of these genes coding for putative antitumor compounds to analyse Algerian strains. In this study, we have highlighted the interesting presence of diverse haloalkalitolerant and haloalkaliphilic strains with potential antitumorigenic, bioactive, and other interesting enzymes. Future work will concentrate on more cloning and sequencing for whole clusters, chemical characteristics, identification by application of mass spectrum, and other enzymatic and biochemical techniques that would be more suitable for better determination of the nature of the elaborated compounds produced by the strains identified in this study particularly of Nocardia sp. Bisk2, Actinopolyspora sp. M5A, and Streptomyces sp. Ig6.

\section{Appendix}

GenBank accession numbers for 16S RNA gene sequences of 13 strains of this study are GB3 (JQ690542), GB1 (JQ690543), ASB (JQ690544), Ig6 (JQ690545), AT1 (JQ690546), HHS1 (JQ690547), Ker5 (JQ690548), Reg1 (JQ690549), A60 (JQ690550), Bisk2 (JQ690551), Tag5 (JQ690552), Bisk4 (JQ690553), and M5A (KJ409655).

\section{Conflict of Interests}

The authors declare that there is no conflict of interests regarding the publication of this paper.

\section{Acknowledgments}

The authors acknowledge Warwick University staff, in particular Dr. Calvo-Bado A. L., Dr. Khalifa A., and Dr. Witcomb L. The authors also acknowledge Professor Naim M. from HCA, Dr. Antri K. USTHB for providing the targeted microorganisms, and Mr. Bouhzila F. from environmental Biotechnology, Polytechnical School, Algiers, for physicalchemical soils parameters determination. The authors give special thanks to Mr. Mohammed A., Mr. Slama G., and Mr. Natèche M. for the help. The authors would also like to thank the anonymous reviewers for the analysis and the enrichment of this paper. In the end, the authors would like to thank the Algerian Ministry of Higher Education and Scientific Research and the University of Warwick for supporting this work. CB has received funding from the European Union's Seventh Framework Programme for research, technological development, and demonstration under Grant no. 289285.

\section{References}

[1] M. Podar and A. L. Reysenbach, "New opportunities revealed by biotechnological explorations of extremophiles," Current Opinion in Biotechnology, vol. 17, no. 3, pp. 250-255, 2006.

[2] S. Subramaniam, "Productivity and attrition: key challenges for biotech and pharma," Drug Discovery Today, vol. 8, no. 12, pp. 513-515, 2003.

[3] K. S. Lam, "New aspects of natural products in drug discovery," Trends in Microbiology, vol. 15, no. 6, pp. 279-289, 2007.

[4] N. Perić-Concha and P. F. Long, "Mining the microbial metabolome: a new frontier for natural product lead discovery," Drug Discovery Today, vol. 8, no. 23, pp. 1078-1084, 2003.

[5] J. Spížek, J. Novotná, T. Řezanka, and A. L. Demain, “Do we need new antibiotics? The search for new targets and new compounds," Journal of Industrial Microbiology and Biotechnology, vol. 37, no. 12, pp. 1241-1248, 2010.

[6] F. A. Rainey and A. Oren, "Extremophile microorganisms and the methods to handle them," in Extremophiles Methods in Microbiology, F. A. Rainey and A. Oren, Eds., vol. 35, pp. 1-25, Academic Press, London, UK, 2006.

[7] Y. Ma, E. A. Galinski, W. D. Grant, A. Oren, and A. Ventosa, "Halophiles 2010: life in saline environments," Applied and Environmental Microbiology, vol. 76, no. 21, pp. 6971-6981, 2010.

[8] L. J. Rothschild and R. L. Mancinelli, "Life in extreme environments," Nature, vol. 409, no. 6823, pp. 1092-1101, 2001. 
[9] D. El Hidri, A. Guesmi, A. Najjari et al., "Cultivation-dependant assessment, diversity, and ecology of haloalkaliphilic bacteria in arid saline systems of southern Tunisia," BioMed Research International, vol. 2013, Article ID 648141, 15 pages, 2013.

[10] G. S. H. Soliman and H. G. Trueper, "Halobacterium pharaonis sp.nov., a new, extremely haloalkaliphilic archaebacterium with low magnesium requirement," Zentralblatt für Bakteriologie Mikrobiologie und Hygiene: I. Abt. Originale C, vol. 3, no. 2, pp. 318-329, 1982.

[11] K. Horikoshi, Alkaliphiles, Wiley Online Library, 2008.

[12] K. Horikoshi, "Alkaliphiles: some applications of their products for biotechnology," Microbiology and Molecular Biology Reviews, vol. 63, no. 4, pp. 735-750, 1999.

[13] H. Takami, Y. Takaki, and I. Uchiyama, "Genome sequence of Oceanobacillus iheyensis isolated from the Iheya Ridge and its unexpected adaptive capabilities to extreme environments," Nucleic Acids Research, vol. 30, no. 18, pp. 3927-3935, 2002.

[14] S. P. Singh, "Extreme environments and extremophiles," in $E$ Book: Environmental Microbiology, pp. 1-35, National Science Digital Library (CSIR), New Delhi, India, 2006.

[15] A. A. Joshi, P. P. Kanekar, A. S. Kelkar et al., "Cultivable bacterial diversity of alkaline Lonar lake, India," Microbial Ecology, vol. 55, no. 2, pp. 163-172, 2008.

[16] H. Hacène, N. Sabaou, N. Bounaga, and G. Lefebvre, "Screening for non-polyenic antifungal antibiotics produced by rare Actinomycetales," Microbios, vol. 79, no. 319, pp. 81-85, 1994.

[17] H. Hacene, K. Kebir, D. S. Othmane, and G. Lefebvre, "HM17, a new polyene antifungal antibiotic produced by a new strain of Spirillospora," Journal of Applied Bacteriology, vol. 77, no. 5, pp. 484-489, 1994.

[18] H. Hacène, F. Daoudi-Hamdad, T. Bhatnagar, J. C. Baratti, and G. Lefebvre, "H107, a new aminoglycoside anti-Pseudomonas antibiotic produced by a new strain of Spirillospora," Microbios, vol. 102, no. 402, pp. 69-77, 2000.

[19] H. Hacěne, F. Rafa, N. Chebhouni et al., "Biodiversity of prokaryotic microflora in El Golea Salt lake, Algerian Sahara," Journal of Arid Environments, vol. 58, no. 3, pp. 273-284, 2004.

[20] S. Boutaiba, H. Hacene, K. A. Bidle, and J. A. Maupin-Furlow, "Microbial diversity of the hypersaline Sidi Ameur and Himalatt Salt Lakes of the Algerian Sahara," Journal of Arid Environments, vol. 75, no. 10, pp. 909-916, 2011.

[21] A. Bouanane-Darenfed, M. L. Fardeau, P. Grégoire et al., "Caldicoprobacter algeriensis sp. nov. a new thermophilic anaerobic, xylanolytic bacterium isolated from an Algerian hot spring," Current Microbiology, vol. 62, no. 3, pp. 826-832, 2011.

[22] A. N. Addou, P. Schumann, C. Spröer, H. Hacene, J. L. Cayol, and M. L. Fardeau, "Melghirimyces algeriensis gen. nov., sp. nov., a member of the family Thermoactinomycetaceae, isolated from a salt lake," International Journal of Systematic and Evolutionary Microbiology, vol. 62, part 7, pp. 1491-1498, 2012.

[23] A. N. Addou, P. Schumann, C. Spröer et al., "Melghirimyces thermohalophilus sp. nov., a thermoactinomycete isolated from an Algerian salt lake," International Journal of Systematic and Evolutionary Microbiology, vol. 63, no. part 5, pp. 1717-1722, 2013.

[24] M. Amziane, F. Metiaz, A. Darenfed-Bouanane et al., "Virgibacillus natechei sp. nov., a moderately halophilic bacterium isolated from sediment of a saline lake in southwest of Algeria," Current Microbiology, vol. 66, no. 5, pp. 462-466, 2013.

[25] T. Bhatnagar, S. Boutaiba, H. Hacene et al., "Lipolytic activity from Halobacteria: screening and hydrolase production," FEMS Microbiology Letters, vol. 248, no. 2, pp. 133-140, 2005.
[26] S. Boutaiba, T. Bhatnagar, H. Hacene, D. A. Mitchell, and J. C. Baratti, "Preliminary characterisation of a lipolytic activity from an extremely halophilic archaeon, Natronococcus sp.," Journal of Molecular Catalysis B: Enzymatic, vol. 41, no. 1-2, pp. 21-26, 2006.

[27] E. B. Shirling and D. Gottlieb, "Methods for characterization of Streptomyces species," International Journal of Systematic Bacteriology, vol. 16, pp. 313-340, 1966.

[28] U. Edwards, T. Rogall, H. Blocker, M. Emde, and E. C. Bottger, "Isolation and direct complete nucleotide determination of entire genes. Characterization of a gene coding for $16 \mathrm{~S}$ ribosomal RNA," Nucleic Acids Research, vol. 17, no. 19, pp. 7843-7853, 1989.

[29] H. Decker, S. Gaisser, S. Pelzer et al., "A general approach for cloning and characterizing dNDP-glucose dehydratase genes from actinomycetes," FEMS Microbiology Letters, vol. 141, pp. 195-201, 1996.

[30] F. Y. Chang and S. F. Brady, "Cloning and characterization of an environmental DNA-derived gene cluster that encodes the biosynthesis of the antitumor substance BE-54017," Journal of the American Chemical Society, vol. 133, no. 26, pp. 9996-9999, 2011.

[31] Y. Ouyang, H. Wu, L. Xie et al., "A method to type the potential angucycline producers in actinomycetes isolated from marine sponges," International Journal of Sciences: Basic and Applied Research, vol. 99, no. 4, pp. 807-815, 2011.

[32] O. S. Kim, Y. J. Cho, K. Lee et al., "Introducing EzTaxon-e: a prokaryotic $16 \mathrm{~S}$ rRNA Gene sequence database with phylotypes that represent uncultured species," International Journal of Systematic and Evolutionary Microbiology, vol. 62, part 3, pp. 716-721, 2012.

[33] K. Tamura, J. Dudley, M. Nei, and S. Kumar, "MEGA4: Molecular Evolutionary Genetics Analysis (MEGA) software version 4.0," Molecular Biology and Evolution, vol. 24, no. 8, pp. 15961599, 2007.

[34] J. D. Thompson, D. G. Higgins, and T. J. Gibson, "CLUSTAL $\mathrm{W}$ : improving the sensitivity of progressive multiple sequence alignment through sequence weighting, position-specific gap penalties and weight matrix choice," Nucleic Acids Research, vol. 22, no. 22, pp. 4673-4680, 1994.

[35] K. Tamura, M. Nei, and S. Kumar, "Prospects for inferring very large phylogenies by using the neighbor-joining method," Proceedings of the National Academy of Sciences of the United States of America, vol. 101, no. 30, pp. 11030-11035, 2004.

[36] N. Saitou and M. Nei, "The neighbor-joining method: a new method for reconstructing phylogenetic trees," Molecular Biology and Evolution, vol. 4, no. 4, pp. 406-425, 1987.

[37] J. Felsenstein, "Confidence limits on phylogenies: an approach using the bootstrap," Evolution, vol. 39, pp. 783-791, 1985.

[38] R. Forar-Laidi, A. Abderrahmane, and A. A. Hocine-Norya, "Identification and antibiosis of a novel actinomycete strain RAF-11 isolated from Iraqi soil," International Journal of Sciences: Basic and Applied Research, vol. 12, no. 1, pp. 141-159, 2013.

[39] E. Phillips and P. Nash, "Culture media," in Manual of Clinical Microbiology, E. H. Lennette, A. Balows, W. J. Hausler Jr., and H. J. Shadomy, Eds., pp. 1064-1065, American Society for Microbiology, Washington, DC, USA, 4th edition, 1985.

[40] A. Ventosa, E. Mellado, C. Sanchez-Porro, and M. C. Marquez, "Halophilic and halotolerant micro-organisms from soils," in Microbiology of Extreme Soils, Soil Biology, P. Dion and C. S. Nautiyal, Eds., vol. 13, pp. 87-115, Springer, Berlin, Germany, 2008. 
[41] J. Wu, T. Guan, H. Jiang et al., "Diversity of actinobacterial community in saline sediments from Yunnan and Xinjiang, China," Extremophiles, vol. 13, no. 4, pp. 623-632, 2009.

[42] A. Meklat, N. Sabaou, A. Zitouni, F. Mathieu, and A. Lebrihi, "Isolation, taxonomy, and antagonistic properties of halophilic actinomycetes in saharan soils of algeria," Applied and Environmental Microbiology, vol. 77, no. 18, pp. 6710-6714, 2011.

[43] E. Pagaling, H. Wang, M. Venables et al., "Microbial biogeography of six salt lakes in Inner Mongolia, China, and a salt lake in Argentina," Applied and Environmental Microbiology, vol. 75, no. 18, pp. 5750-5760, 2009.

[44] "Genomes OnLine Database" http://genomesonline.org/cgibin/GOLD/index.cgi.

[45] J. Hamedi, F. Mohammadipanah, and A. Ventosa, "Systematic and biotechnological aspects of halophilic and halotolerant actinomycetes," Extremophiles, vol. 17, pp. 1-13, 2013.

[46] A. K. Chaudhary, D. Dhakal, and J. K. Sohng, "An insight into the "-omics" based engineering of streptomycetes for secondary metabolite overproduction," BioMed Research International, vol. 2013, Article ID 968518, 15 pages, 2013.

[47] M. Metsä-Ketelä, L. Halo, E. Munukka, J. Hakala, P. Mäntsäla, and K. Ylihonko, "Molecular evolution of aromatic polyketides and comparative sequence analysis of polyketide ketosynthase and 16S ribosomal DNA genes from various Streptomyces species," Applied and Environmental Microbiology, vol. 68, no. 9, pp. 4472-4479, 2002.

[48] C. P. Ridley, Y. L. Ho, and C. Khosla, "Evolution of polyketide synthases in bacteria," Proceedings of the National Academy of Sciences of the United States of America, vol. 105, no. 12, pp. 45954600, 2008.

[49] M. Steffensky, A. Mühlenweg, Z. X. Wang, S. M. Li, and L. Heide, "Identification of the novobiocin biosynthetic gene cluster of Streptomyces spheroides NCIB 11891," Antimicrobial Agents and Chemotherapy, vol. 44, no. 5, pp. 1214-1222, 2000.

[50] W. Liu and B. Shen, "Genes for production of the enediyne antitumor antibiotic C-1027 in Streptomyces globisporus are clustered with the cagA gene that encodes the C-1027 apoprotein," Antimicrobial Agents and Chemotherapy, vol. 44, no. 2, pp. 382-392, 2000

[51] A. Ramos, F. Lombó, A. F. Braña, J. Rohr, C. Méndez, and J. A. Salas, "Biosynthesis of elloramycin in Streptomyces olivaceus requires glycosylation by enzymes encoded outside the aglycon cluster," Microbiology, vol. 154, no. 3, pp. 781-788, 2008.

[52] W. Li, A. Khullar, S. Chou, A. Sacramo, and B. Gerratana, "Biosynthesis of sibiromycin, a potent antitumor antibiotic," Applied and Environmental Microbiology, vol. 75, no. 9, pp. 2869-2878, 2009.

[53] M. K. Kharel, S. E. Nybo, M. D. Shepherd, and J. Rohr, "Cloning and characterization of the ravidomycin and chrysomycin biosynthetic gene clusters," ChemBioChem, vol. 11, no. 4, pp. 523-532, 2010.

[54] T. M. Yoon, J. W. Kim, J. G. Kim, W. G. Kim, and J. W. Suh, "Talosins A and B: new isoflavonol glycosides with potent antifungal activity from Kitasatospora kifunensis MJM341 I. Taxonomy, fermentation, isolation, and biological activities," Journal of Antibiotics, vol. 59, no. 10, pp. 633-639, 2006.

[55] L. Kaysser, E. Wemakor, S. Siebenberg et al., "Formation and attachment of the deoxysugar moiety and assembly of the gene cluster for caprazamycin biosynthesis," Applied and Environmental Microbiology, vol. 76, no. 12, pp. 4008-4018, 2010.
[56] G. Zhang, H. Zhang, S. Li et al., "Characterization of the amicetin biosynthesis gene cluster from Streptomyces vinaceusdrappus NRRL 2363 implicates two alternative strategies for amide bond formation," Applied and Environmental Microbiology, vol. 78, no. 7, pp. 2393-2401, 2012.

[57] S. D. Lee, "Nocardia jejuensis sp. nov., a novel actinomycete isolated from a natural cave on Jeju Island, Republic of Korea," International Journal of Systematic and Evolutionary Microbiology, vol. 56, no. 3, pp. 559-562, 2006.

[58] R. Margesin and F. Schinner, "Potential of halotolerant and halophilic microorganisms for biotechnology," Extremophiles, vol. 5, no. 2, pp. 73-83, 2001.

[59] A. Oren, "Industrial and environmental applications of halophilic microorganisms," Environmental Technology, vol. 31, no. 8-9, pp. 825-834, 2010.

[60] O. Selama, P. James, F. Nateche, E. M. H. Wellington, and H. Hacène, "The world bacterial biogeography and biodiversity through databases: a case study of NCBI Nucleotide Database and GBIF Database," BioMed Research International, vol. 2013, Article ID 240175, 11 pages, 2013. 

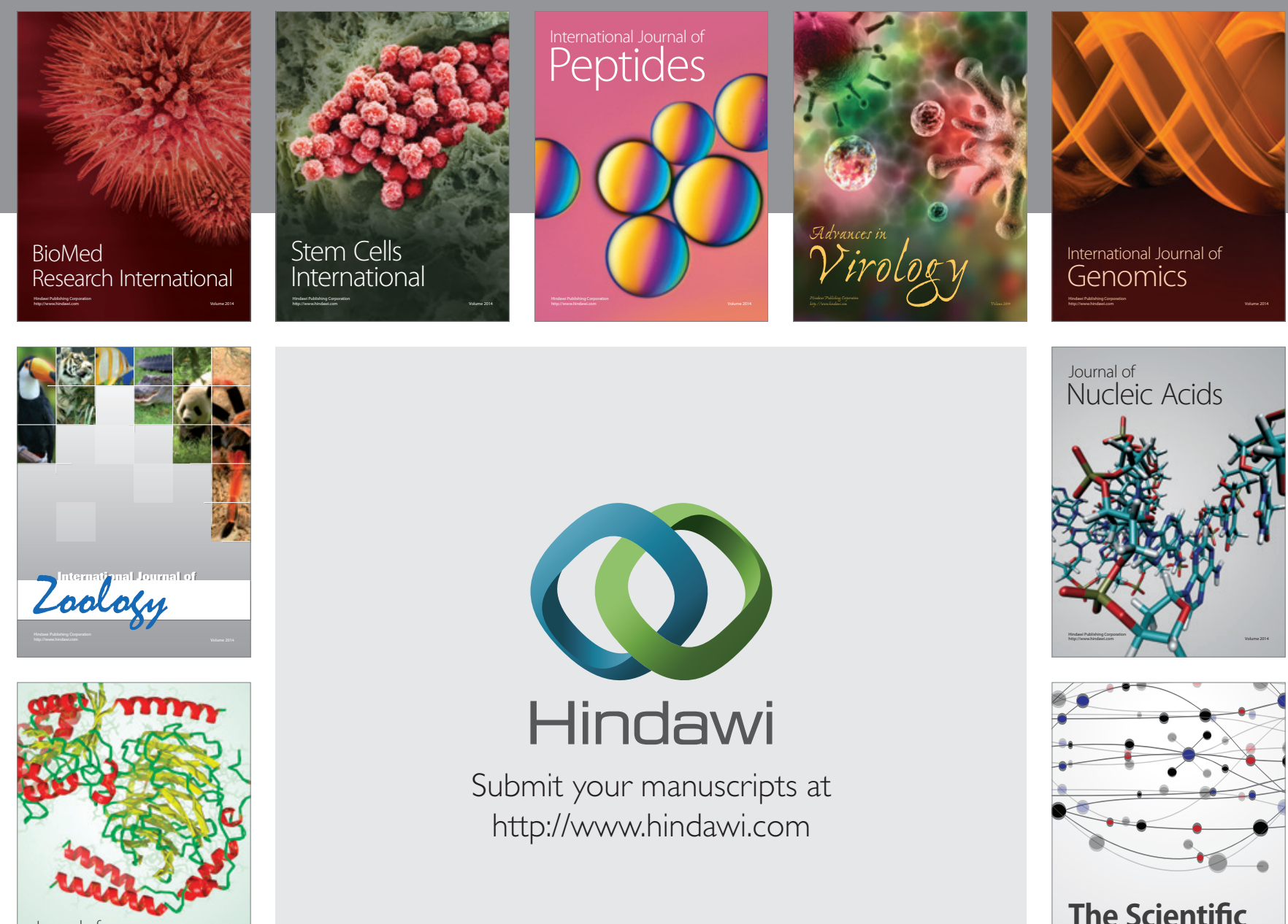

Submit your manuscripts at

http://www.hindawi.com

Journal of
Signal Transduction
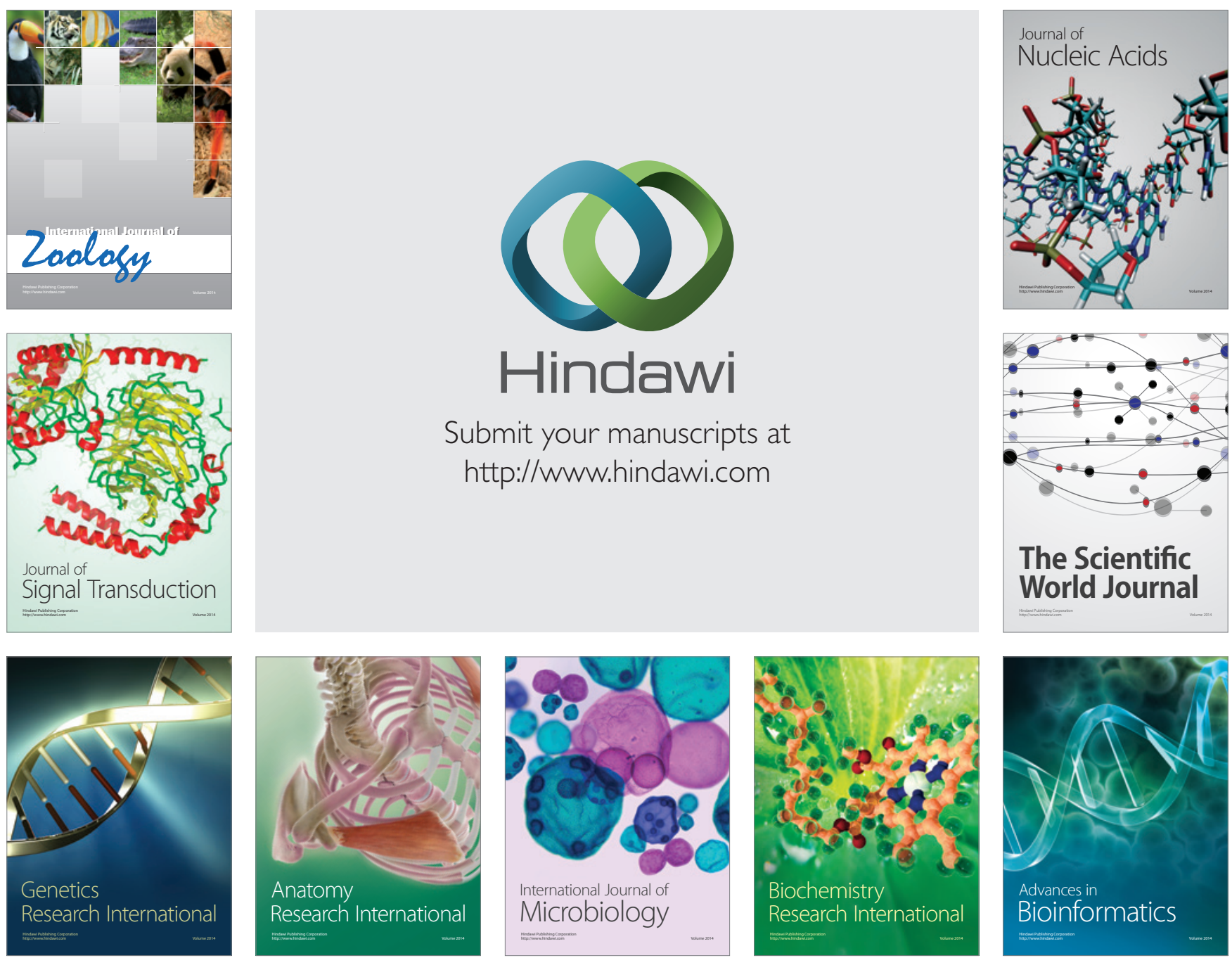

The Scientific World Journal
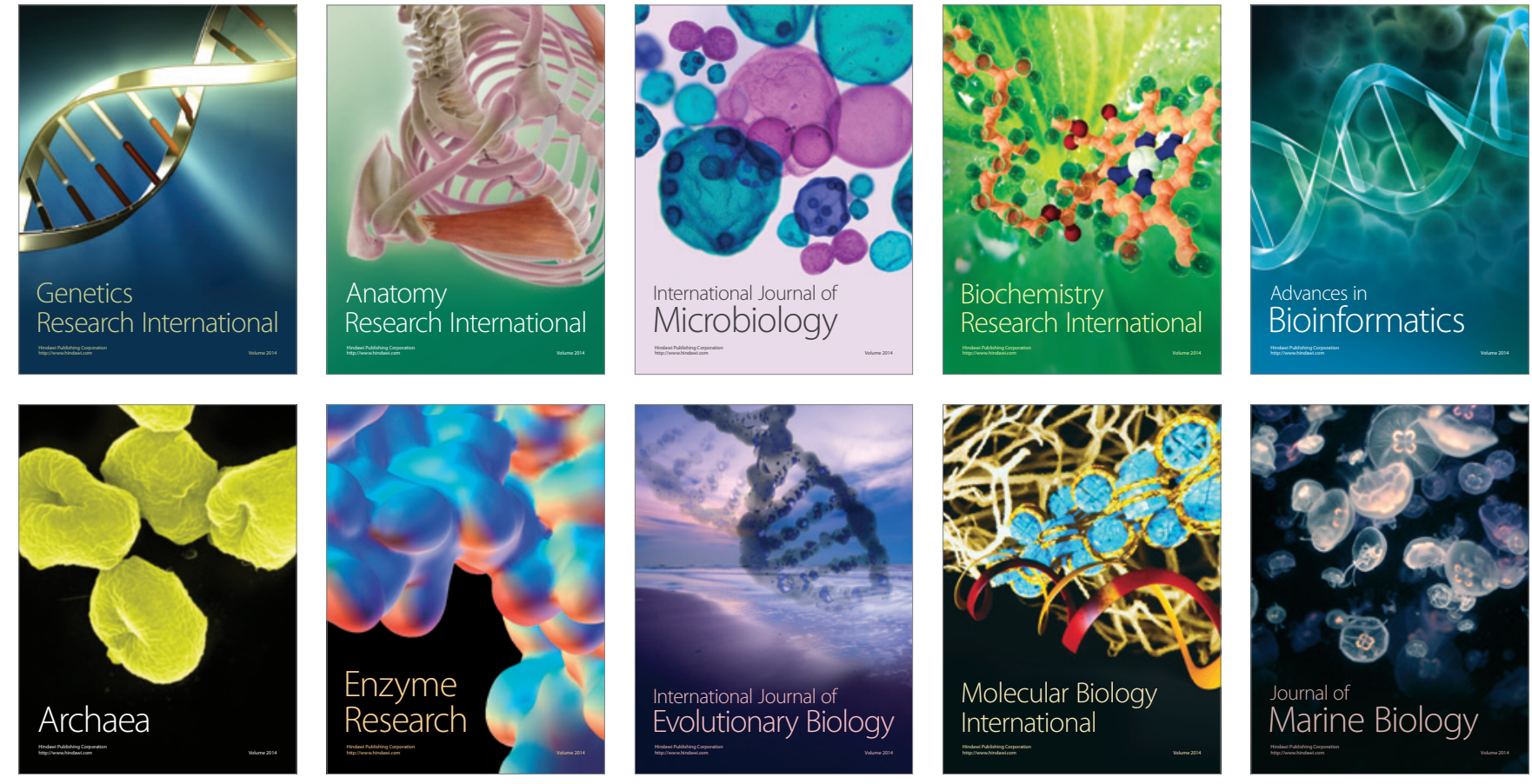